УДК 025.5:001.891:[001.89:005.71](477)

Самчук Лариса Іванівна

завідувач відділу наукової інформаційно-бібліографічної діяльності

Державної науково-педагогічної бібліотеки України імені В. О. Сухомлинського, м. Київ, Україна

inform_bibl@i.ua

\title{
ДОСВІД ДІЯЛЬНОСТІ ДЕРЖАВНОЇ НАУКОВО-ПЕДАГОГІЧНОЇ БІБЛІОТЕКИ УКРАЇНИ ІМЕНІ В. О. СУХОМЛИНСЬКОГО ЩОДО ІНФОРМАЦЙНО- БІБЛІОГРАФІЧНОГО ЗАБЕЗПЕЧЕННЯ НАУКОВИХ ДОСЛІДЖЕНЬ НАЦІОНАЛЬНОЇ АКАДЕМІЇ ПЕДАГОГІЧНИХ НАУК УКРАЇНИ
}

\begin{abstract}
Анотація. Перехід суспільства до нових економічних і політичних реалій зумовив радикальні зміни в системі діяльності бібліотек, зокрема пошук нових парадигм інформаційно-бібліографічного обслуговування в умовах великої академічної бібліотеки. У статті висвітлено результати діяльності Державної науково-педагогічної бібліотеки України імені В. О. Сухомлинського упродовж 2002-2014 pр. щодо інформаційно-бібліографічного забезпечення наукових досліджень Національної академії педагогічних наук України, спрямованого на розв'язання проблем, що постали перед освітянською галуззю України на сучасному етапі. Окреслено перспективи діяльності Книгозбірні у цьому напрямі.
\end{abstract}

Ключові слова: Державна науково-педагогічна бібліотека України імені В. О. Сухомлинського; науково-інформаційна діяльність; інформаційно-бібліографічне забезпечення; наукові дослідження; структурований бібліографічний список.

\section{1. ВСТУП}

Постановка проблеми. У Законі України «Про Національну програму інформатизації» визначено, що стратегічним завданням у нашій державі на сучасному етапі $\epsilon$ «розв’язання проблеми забезпечення інформаційних потреб та інформаційної підтримки соціально-економічної, екологічної, науково-технічної, оборонної, національно-культурної та іншої діяльності у сферах загальнодержавного значення» [24].

У численних публікаціях із питань інформаційної діяльності терміни «обслуговування» i «забезпечення» вживаються в різних словосполученнях: «довідково-інформаційне забезпечення», «бібліотечно-бібліографічне обслуговування», «інформаційне забезпечення», «інформаційно-бібліографічне обслуговування» та ін. Інформаційне обслуговування передбачає, що ініціатива йде від спеціаліста й інформаційна система функціонує, як правило, в режимі «запит - відповідь», тобто задовольняє окремі запити, постійні або разові. Інформаційне забезпечення - це процес постійної підтримки наукового дослідження від зародження наукової ідеї до втілення у практику результатів дослідження, головним об'єктом є конкретні наукові теми, передбачені науковими планами установ і комплексними програмами досліджень. Цей напрям роботи є новою, досконалішою формою інформаційної діяльності, невід'ємною складовою наукової розробки.

Аналіз останніх досліджень та публікацій. У бібліотечній справі накопичено великий досвід інформаційної підтримки наукової діяльності. У практику діяльності бібліотек інформаційна діяльність увійшла в 1966 р. після ухвалення Радою Міністрів СРСР постанови № 916 «Про загальнодержавну систему науково-технічної інформації» [20]. 3 цього часу в книгозбірнях бібліотечно-бібліографічне обслуговування поєднується 3 інформаційним. Це нерозривний процес, у якому застосовуються 
бібліотечні, бібліографічні та інформаційні форми роботи: Дні інформації, Дні спеціаліста, тематичні виставки нових надходжень, інформування в режимі вибіркового розповсюдження інформації, підготовка бібліографічних посібників тощо.

Уперше термін «інформаційне забезпечення науково-технічних розроблень» було введено у 1980 р. і визначено як сукупність процесів 3 підготовки і представлення спеціально підготовленої науково-технічної інформації для розв'язання управлінських і науково-технічних завдань відповідно до етапів їх виконання. Термін «довідковоінформаційне обслуговування» визначався як сукупність процесів із задоволення інформаційних запитів користувачів науково-технічної інформації [6].

Питанню науково-інформаційної діяльності бібліотек присвячено десятки наукових публікацій зарубіжних i вітчизняних науковців, зокрема докторські i кандидатські дисертації, монографії тощо. Зокрема, М. Соколова [28] презентує історичний огляд канадської системи інформаційного забезпечення науки, починаючи 3 1920-х pр. Питанням організації і форм інформаційного обслуговування вчених 3 використанням інформаційно-комунікаційних технологій присвячено праці Н. Берьозкіної [3] і О. Коротенко [15].

Теоретичні аспекти інформаційного забезпечення наукової діяльності в умовах бібліотек досліджено в науковому доробку Л. Бейліса [2]. У роботах В. Вергунова [5], Н. Артамонової [1], Ю. Пасмор [21], Н. Петриної та Л. Ониксимової [22] переконливо доведено вирішальне значення бібліотек в інформаційно-бібліотечному забезпеченні наукових досліджень, накреслено перспективи розвитку і використання накопичених ресурсів із застосуванням новітніх інформаційних технологій, наголошено на гострих проблемах сьогодення, шляхах їх подолання.

Метою статті $\epsilon$ висвітлення досвіду Державної науково-педагогічної бібліотеки України імені В. О. Сухомлинського (ДНПБ України ім. В. О. Сухомлинського) щодо забезпечення цілеспрямованої інформаційно-бібліографічної підтримки наукових досліджень установ Національної академії педагогічних наук України (НАПН України.

\section{2. РЕЗУЛЬТАТИ ДОСЛІДЖЕННЯ}

Головною метою ДНПБ України ім. В. О. Сухомлинського $\epsilon$ науковоінформаційне забезпечення розвитку вітчизняної педагогічної науки, освіти і практики первинними i вторинними документами у традиційній й електронній формі, професійних інформаційних потреб учених і практиків галузі та інших категорій користувачів, що навчаються й займаються загальною і спеціальною самоосвітньою діяльністю [26, с. 18].

Завдяки тісним зв'язкам з науковцями НАПН України фахівці ДНПБ України ім. В. О. Сухомлинського узгоджують свою інформаційну роботу 3 діяльністю іiі установ. Перед науковцями відділу наукової інформаційно-бібліографічної діяльності

(ВНІБД) Книгозбірні постала необхідність удосконалення інформаційнобібліографічної роботи, завдяки чому забезпечення наукових розробок НАПН України було б оперативним, повним та кваліфікованим. Науковці дійшли висновку щодо доцільності укладання компактних за обсягом бібліографічних посібників, які отримали найменування «структуровані бібліографічні списки» (СБС) [23, с. 79]. Оскільки основну роботу щодо збору i систематизації матеріалу виконують бібліографи-укладачі, багато залежить не тільки від їхнього досвіду бібліографічної роботи, але й від набутих знань в окремих галузях педагогічної науки. Як правило, бібліограф-укладач, уважно аналізуючи наукові публікації з теми, самостійно групує матеріал і вносить необхідні зміни до структури СБС. Проте під час створення СБС, призначених для інформаційного забезпечення наукових робіт учених НАПН України, 
важливим є високий рівень якості цих документів. Один із шляхів досягнення цього співпраця науковців і бібліографів. Тісне співробітництво з ученими на всіх етапах роботи з підготовки СБС забезпечує кваліфікований підбір літератури, класифікацію документів і визначення термінів відповідно до сучасного стану педагогічної науки, раціональний вибір структури СБС. 3 метою чіткої організації інформаційнобібліографічної підтримки наукових досліджень НАПН України розроблено форму подання листа-запиту, у якому вказується замовник (установа НАПН України), тема запиту, види документів, хронологічні межі, вид надання інформації, термін виконання, спосіб доставляння.

Серед СБС, складених протягом 2002-2014 pр., відзначаються грунтовністю, повнотою, широким охопленням матеріалу: «Життєва компетентність особистості», «Зміст та методичне забезпечення Державного стандарту початкової загальної освіти», «Метод проектів у сучасній школі», «Створення концепції профільної школи», «Теорія і практика проектування інноваційних педагогічних систем 12-річної школи», «Моделі інноваційного розвитку різних типів навчальних закладів» тощо. Слід зауважити, що метою створення зазначених списків $є$ підтримка наукових робіт установ НАПН України, спрямованих на розв'язання проблем, що постали перед освітянською галуззю України на сучасному етапі.

Так, зміст освіти не в повному обсязі відповідає потребам суспільства у кваліфікованих фахівцях, не спрямований на набуття необхідної життєвої компетентності. Ті зміни, які відбувалися в галузі освіти України за останні 15 років, переобтяжили навчальні програми і підручники необов'язковим для загальної середньої освіти матеріалом. Одним зі шляхів оновлення змісту освіти й узгодження його із сучасними потребами, інтеграції до європейського і світового освітніх просторів $\epsilon$ орієнтація навчальних програм на набуття таких базових знань, які забезпечують як потреби суспільства у кваліфікованих кадрах, так і перспективи окремої особистості щодо подальшого професійного вдосконалення і підвищення рівня освіти. Тому у процесі інформаційно-бібліографічного забезпечення наукової роботи лабораторії педагогічних інновацій Інституту педагогіки НАПН України «Життєва компетентність особистості» (керівник - I. Срмаков, ст. наук. співроб. лабораторії, канд. іст. наук) велика увага була приділена систематизації матеріалу. Практичним втіленням результатів теоретичного пошуку науковців із вищевказаної теми стало видання посібника «Життєва компетентність особистості: від теорії до практики» [10]. Схема СБС розроблялася спільно $з$ науковим керівником роботи. Список складається з семи розділів, кожний з яких має кілька підрозділів. Хронологічні рамки - 1923-2002 pр. Для прикладу, у розділі «Життєтворча парадигма 12-річної середньої школи» зібрано матеріал про історичний розвиток школи як школи життя, моделі іiі реформування у різних країнах світу. Наступний розділ - «Феномен компетентності й успіху» розкриває поняття компетентності i містить документи про життєвий досвід i компетентний життєвий шлях особистості. Типологічну класифікаційну характеристику життєвої і соціальної компетентності надає третій розділ. Проблеми життєвого і професійного самовизначення випускника висвітлено у розділі «Освітні результати. Освітні результати у вітчизняній і зарубіжній педагогічній практиці». Заключні розділи охоплюють документи, присвячені використанню перспективних технологій у розвитку життєвої і соціальної компетентності.

У «Національній доктрині розвитку освіти» [19] наголошено, що держава повинна забезпечувати різноманітність типів навчальних закладів, варіативність навчальних програм, індивідуалізацію навчання і виховання. На рівні старшої школи постала необхідність створити умови для профільного навчання як у загальноосвітніх навчальних закладах, так і на базі професійно-технічних. Ситуація, що склалася на 
ринку праці, потребує нових підходів до організації освіти у старшій школі, нагального iï переструктурування, а саме - створення такої профільної школи, яка б відповідала європейським стандартам і задовольняла потреби суспільства. У 2003 р. колективом науковців Інституту педагогіки НАПН України під керівництвом академіка НАПН України Н. Бібік і члена-кореспондента НАПН України М. Бурди розроблено «Концепцію профільного навчання в старшій школі» [14], яка стала результатом дослідження теоретичних проблем змісту шкільної освіти. У концепції розкрито сутність, мету та завдання профільного навчання, обгрунтовано його структуру і форми організації, висвітлено питання здійснення допрофільної підготовки. Інформаційнобібліографічне забезпечення наукової роботи Відділення дидактики, методики та інформаційних технологій в освіті НАПН України «Створення концепції профільної школи» (керівник - Н. Бібік, академік-секретар Відділення дидактики, методики та інформаційних технологій в освіті НАПН України) втілено у СБС з вищезазначеної теми. У ньому висвітлено вітчизняний досвід профільного навчання, починаючи від «Уставу гімназій і прогімназій» 1864 р. до часів незалежної України, зарубіжний досвід iз заявленої теми, представлено наукові праці видатних педагогів і громадських діячів про політехнічне і трудове навчання і виховання, упровадження профільного навчання на сучасному етапі в Україні, Росії та інших країнах, джерела про систему політехнічного навчання в сільській школі, питання психологічних особливостей професійного самовизначення старшокласників. В 11 розділах зібрано 312 назв документів. Хронологічними рамками добору матеріалів є період з 1902 по 2003 р. Вищезазначений список став базою для створення науково-допоміжного бібліографічного покажчика «Профільне навчання в старшій школі: шляхи розвитку», який надрукувала газета «Освіта України» як спеціальний випуск [25]. Його отримали понад 150 тис. передплатників.

Суттєвим $є$ доробок науковців НАПН України, які досліджували проблеми науково-методичного i дидактичного забезпечення реалізації змісту шкільної i дошкільної освіти. У 2003 р. завершено дослідження, яке передбачало формування змісту початкової освіти у новій 12-річній школі та створення науково-методичного і дидактичного забезпечення навчально-виховного процесу в цій їі ланці. Інформаційнобібліографічне забезпечення наукової роботи Відділення дидактики, методики та інформаційних технологій в освіті НАПН України «Зміст та методичне забезпечення Державного стандарту початкової загальної освіти» (керівник - Н. Бібік, академіксекретар Відділення дидактики, методики та інформаційних технологій в освіті НАПН України) представлено у СБС, що складається з чотирьох розділів: «Освітня галузь «Мова і література», «Освітня галузь «Математика», «Інтегрований курс «Основи здоров'я», «Освітня галузь «Людина і світ». У них висвітлюється широкий спектр питань, пов'язаних з історичним розвитком методики викладання різних предметів у початковій школі й досягненнями вітчизняних науковців у даній царині у незалежній Україні. До списку включено 808 назв документів, хронологічні рамки - 1931-2003 рр. Матеріали СБС були використані науковцями під час підготовки навчальних програм для 3-4 класів із таких предметів: українська мова, читання, математика, трудове навчання; курсів «Я і Україна» та «Основи здоров'я»; підручників для 3 класу: «Рідна мова», «Українська мова», «Читанка», «Математика», «Трудове навчання», «Основи здоров'я», «Я і Україна». Підготовлено рукописи підручників із цих же предметів для 4 класу. Як складові навчально-методичних комплектів, створено навчальний посібник iз позакласного читання (2 клас), робочі зошити 3 математики i природознавства (3 клас), посібник для тестової перевірки навчальних досягнень учнів 3 української мови (2-3 класи), методичний посібник «Навчання рідної мови в 3 класі», а також 
навчальний посібник «Післябукварик» для завершального періоду навчання грамоти першокласників [11, с. 61-62].

Розвиток освіти XXI століття спонукає до запровадження в навчально-виховному процесі інноваційних технологій, сучасних концепцій, програм, методик. Найдоцільнішим 3 інновацій $\epsilon$ метод проектів. Він спрямований на розвиток пізнавальних здібностей школярів, формування вмінь самостійно знаходити шляхи розв'язання проблем через різноманітні форми діяльності. Інформаційнобібліографічне забезпечення наукової роботи лабораторії педагогічних інновацій Інституту педагогіки НАПН України «Метод проектів у сучасній школі» (керівник I. Срмаков, канд. іст. наук) здійснювали в 2003 р. наукові співробітники ВНІБД. Результатом НДР стало видання посібника «Метод проектів: традиції, перспективи, життєві результати» [18], що містить джерельну базу роботи у вигляді грунтовного СБС «Метод проектів у сучасній школі: інформаційний супровід» (238 назв). Також лабораторією спільно з ДНПБ України ім. В. О. Сухомлинського проведено тематичну конференцію на базі Ліцею міжнародних відносин № 51 м. Кисва експериментального майданчика 3 упровадження методу проектів у навчальновиховний процес з обдарованими дітьми.

У 2007 р. постановою Кабінету Міністрів України затверджено Державну цільову соціальну програму «Школа майбутнього» на 2007-2010 pp. [8], мета якої полягає в удосконаленні механізму надання освітніх послуг, випробуванні інноваційних моделей новітніх навчальних закладів, діяльність яких спрямована на випереджальний розвиток системи освіти. У межах НДР «Моделі інноваційного розвитку загальноосвітнього навчального закладу», яка здійснювалась лабораторією педагогічних інновацій Інституту педагогіки НАПН України протягом 2007-2009 рр. (керівники - канд. пед. наук I. Срмаков, Г. Щекатунова), зокрема обгрунтовано теоретичні й методологічні засади і принципи прогностичного моделювання інноваційного розвитку шкільної освіти як «Школи майбутнього». Фахівцями ВНІБД проаналізовано джерельну базу 3 теми й підготовлено СБС «Моделі інноваційного розвитку 12-річної школи» (532 назви), який складається з таких розділів: «Моделювання і прогнозування «Шкіл майбутнього»: історичні уроки» (2007р.), «Репертуар ключових компетентностей учнів загальноосвітніх шкіл» (2008р.), «Теорія і практика розроблення прогностичних моделей шкіл майбутнього» (2009р.). Також проведено низку заходів, присвячених проблемам модернізації й інноваційного розвитку навчальних закладів у контексті компетентнісно орієнтованого підходу, зокрема педагогічні читання «Компетентнісний потенціал проектної діяльності у загальноосвітньому навчальному закладі» (на базі гімназії № 32 м. Києва), Міжнародну науково-практичну конференцію «Моделі інноваційного розвитку 12-річної школи» (на базі гімназії № 117 імені Лесі Українки м. Києва) тощо.

Щоб бути на рівні викликів XXI століття, освіта має носити випереджальний характер, тобто бути націленою на майбутнє, на розв'язання проблем нового століття, розвиток ключових компетентностей вихованців, формування в них проектної культури, нових способів мислення й діяльності. Це вимагає докорінного переосмислення фундаментальних засад 11-річної школи, посилення іiї компетентнісної спрямованості, суть якої полягає в переорієнтації від загальної підготовки до освоєння способів інтеграції в сучасне суспільство. Перший досвід компетентнісно спрямованої освіти узагальнила Всеукраїнська науково-практична конференція «Компетентнісно спрямована освіта: перший досвід, порівняльні підходи, перспективи», яка відбулася у 2011 р. з ініціативи Інституту інноваційних технологій і змісту освіти МОН України, Інституту педагогіки НАПН України й ДНПБ України ім. В. О. Сухомлинського. Результати конференції оприлюднені у збірнику [13], складовою якого став СБС за 
темою дослідження (204 назви). У списку висвітлено широкий спектр питань: загальні стратегії компетентнісно спрямованої освіти в контексті діалогу культур: Україна країни $\mathrm{CC}$; педагогічні інновації у навчанні дітей 3 особливими потребами; зміст компетентнісно спрямованої освіти; педагогічні технології для компетентнісно спрямованого навчання.

Інновації - це сутність постіндустріального, інформаційного суспільства, постійні зміни якого проблематизують буття людини. Особливе значення цей феномен має для освітньої галузі України. Інновації в освіті «характеризуються новизною, спрямованою на якісне поліпшення освітнього процесу i результати, та відображаються в удосконалених чи нових: освітніх складових; освітніх технологіях; наукових та науково-методичних розробках, технічних засобах, нормативно-правових документах, що регламентують діяльність навчальних закладів і установ освіти та їх відносини 3 іншими установами» [4, с. 32]. У цьому контексті заслуговує уваги робота над практико зорієнтованим посібником «Інновації в сучасній школі в контексті діалогу педагогічних культур» [12], у якому розкриваються концептуальні засади інноваційного розвитку загальноосвітніх навчальних закладів України, дається сутнісна характеристика інноватики як стрижневої домінанти педагогічної компаративістики, а також розпочато діалог педагогічних культур країн світу щодо усвідомлення місії інноваційного закладу освіти. Були опрацьовані вторинні інформаційні ресурси, здійснювався пошук інформації за темою, зібрано бібліографію за 1982-2010 рр., підготовлено СБС «Інноваційні школи як педагогічний феномен» (109 назв).

Проблема обдарованості в наш час стає все більш актуальною. Це насамперед пов'язано з потребою суспільства в неординарних творчих особистостях. Невід'ємною складовою державної діяльності у цьому напрямі $\epsilon$ створення відповідних умов i можливостей розкриття, розвитку й реалізації талантів молоді. Зазначені завдання задекларовано в Законах України, указах Президента, Національній доктрині розвитку освіти України у XXI столітті (2002р.), Концепції державної програми роботи 3 обдарованою молоддю на 2006-2010 роки (2006 р.). 3 цією ж метою діють державні програми, запроваджено іменні стипендії переможцям міжнародних й всеукраїнських олімпіад, Всеукраїнського конкурсу наукових робіт учнів - членів Малої академії наук Україні, стипендії Кабінету Міністрів України переможцям олімпіад з української мови та літератури [7]. Розпорядженням Кабінету Міністрів України від 8 серпня 2007 р. № 635-р було створено Інститут обдарованої дитини НАПН України, головною метою діяльності якого $є$ необхідність поліпшення науково-методичного й організаційноспонукального забезпечення функціонування системи виявлення, розвитку і підтримки дітей і молоді.

Упродовж 2013-2015 pр. науковцями відділу підтримки обдарованості та міжнародної співпраці Інституту обдарованої дитини НАПН України здійснюється НДР на тему «Науково-методичні засади підтримки обдарованих дітей, схильних до дослідницької діяльності» (керівник - канд. пед. наук Н. Поліхун). Протягом 20132014 pp. науковці систематично отримували інформацію про нові надходження 3 вищеозначеної теми, до Всеукраїнської науково-практичної конференції «Дослідницький компонент у діяльності загальноосвітніх навчальних закладів та позашкільних закладів освіти: ретроспектива і перспектива» (2013 р.), організованої Інститутом обдарованої дитини НАПН України і проведеної за підтримки ДНПБ України ім. В. О. Сухомлинського, ВНІБД підготовлено каталог виставки «Вітчизняний та зарубіжний досвід роботи 3 обдарованими дітьми». Мета роботи - сприяти практичному втіленню принципів навчання і виховання обдарованих дітей в Україні, поглибленню наукових досліджень у цій сфері, узагальненню передового педагогічного досвіду й упровадженню його в практику сучасних навчальних закладів. Каталог 
охоплює 252 назви документів і складається 3 трьох розділів, у яких презентовано внесок вітчизняних i зарубіжних дослідників у розробку проблеми дитячої обдарованості. Каталог виставки опубліковано у збірнику матеріалів конференції [9].

\section{3. ВИСНОВКИ ТА ПЕРСПЕКТИВИ ПОДАЛЬШИХ ДОСЛІДЖЕНЬ}

Отже, на підставі проведеного аналізу діяльності ДНПБ України ім. В. О. Сухомлинського можна зробити такі висновки: інформаційно-бібліографічне забезпечення наукових досліджень є одним із пріоритетних напрямів роботи, і надалі ця діяльність буде цілеспрямовано удосконалюватися. У процесі інформаційного забезпечення наукових проектів НАПН України підвищився фаховий рівень усіх учасників інформаційної діяльності - як виробників бібліографічної продукції, так і їі споживачів; науковцям була надана значна допомога у формуванні джерельної бази, яка сприяла якісному здійсненню досліджень.

Перспективним напрямом інформаційно-бібліографічного забезпечення галузі в наукових дослідженнях, зокрема 3 вивчення історії вітчизняної педагогічної науки, освіти та практики вважаємо широку репрезентацію рідкісних видань, які ввійшли до складу наукового об'єкта ДНПБ України ім. В. О. Сухомлинського «Документи психолого-педагогічного та історико-культурного напряму XVIII - початку XX століття» і $є$ національним культурним надбанням [17, с. 275].

Підвищення ролі наукових бібліотек у суспільстві потребує постійного удосконалення їхніх організаційних структур, інформаційного обслуговування, впровадження нових технологій, підвищення професійного рівня працівників, які займаються інформаційною діяльністю. Тільки за такого підходу можливе якісне, оперативне, оптимальне забезпечення інформаційної підтримки науки.

\section{СПИСОК ВИКОРИСТАНИХ ДЖЕРЕЛ}

1. Артамонова Н. Система інформаційного забезпечення медичної науки в Україні : монографія / Н. Артамонова. - Харків : Міськдрук, 2010. - 371 с.

2. Бейліс Л. І. Теоретичні аспекти у інформаційного забезпечення наукової діяльності в бібліотеках / Л. І. Бейліс // Наук. пр. Держ. наук.-пед. б-ки ім. В. О. Сухомлинського / АПН України, ДНПБ України ім. В. О. Сухомлинського. - Київ, 2008. - Вип. 1 : Науково-інформаційне забезпечення освітянської галузі України. - С. 37-44. - Бібліогр.: 8 назв.

3. Берёзкина Н. Ю. Новые возможности информационно-библиотечного обслуживания ученых (на примере ЦНБ НАН Беларуси) / Н. Ю. Берёзкина // Библиотеки национальных академий наук: проблемы функционирования, тенденции развития : науч.-практ. и теорет. сб. / НАН Украины, Нац. б-ка Украины им. В. И. Вернадского [и др.]. - Киев, 2012. - Вып. 10. - С. 180-186.

4. Біла книга національної освіти України / за заг. ред. В. Г. Кременя ; НАПН України. - Київ : Інформ. системи, 2010. - $342 \mathrm{c.}$

5. Вергунов В. А. Стан та перспективи інформаційно-бібліотечного забезпечення наукових досліджень аграрної галузі України / В. А. Вергунов // Бібліотекознавство. Документознавство. Інформологія. - 2010. - № 3. - С. 32-42. - Бібліогр.: 10 назв.

6. ГОСТ 7.27-80. Научно-информационная деятельность. Основные термины и определения. Введен 01.01.1982. - М. : Изд-во стандартов, 1981. - 14 с.

7. Грищук Ю. В. Підтримка обдарованої учнівської молоді: нормативно-правовий та соціальнопедагогічний аспекти / Грищук Юлія Володимирівна // Освітол. дискурс. - 2014. - № 1. - С. 46-57. - Бібліогр.: 16 назв.

8. Державна цільова соціальна програма «Школа майбутнього» на 2007-2010 роки : затв. постановою Каб. Міністрів України від 30 серп. 2007 р. № 1071 // Офіц. вісн. України. - 2007. № 66. - С. 2543.

9. Дослідницький компонент у діяльності загальноосвітніх навчальних закладів та позашкільних закладів освіти: ретроспектива і перспектива : матеріали Всеукр. наук.практ. конф., 21 листоп. 
2013 р. / МОН України, НАПН України, Ін-т обдар. дитини НАПН України [та ін.]. - Київ, 2013. 292 c.

10. Життєва компетентність особистості: від теорії до практики : наук.метод. посіб. / АПН України, Ін-т педагогіки, ДНПБ України ім. В. О. Сухомлинського [та ін.] ; [за наук. ред. І. Г. Срмакова]. Запоріжжя : Центріон, 2005. - 640 с. - Бібліогр.: с. 607-632.

11. Звіт про роботу Академії педагогічних наук України за 2003 рік / АПН України ; [упоряд.: О. І. Ляшенко, Т. К. Полонська]. - Київ : [б. в.], 2004. -357 с.

12. Інновації в сучасній школі в контексті діалогу педагогічних культур : практико зорієнт. посіб. / Інт інновац. технологій і змісту освіти МОНмолодьспорту України, Ін-т педагогіки НАПН України, ДНПБ України ім. В. О. Сухомлинського [та ін.]. - Київ, 2012. - 351 с.

13. Компетентнісно спрямована освіта: перший досвід, порівняльні підходи, перспективи : матеріали Всеукр. наук.-практ. конф., 28 квіт. 2011 р. / Ін-т інновац. технологій і змісту освіти МОНмолодьспорту України, Ін-т педагогіки НАПН України, Держ. наук.-пед. б-ка України ім. В. О. Сухомлинського ; [редкол.: Федоренко О. А. та ін. ; заг. ред.: Срмаков І. Г. та ін.]. - Київ, 2011. $-643 \mathrm{c}$.

14. Концепція профільного навчання в старшій школі : затв. рішенням колегії М-ва освіти і науки України від 25.09.03 № 10/12-2 / АПН України, Ін-т педагогіки ; уклад.: Л. Березівська, Н. Бібік, М. Бурда [та ін.] // Інформ. зб. М-ва освіти і науки України. - 2003. - № 24. - С. 3-15.

15. Коротенко Е. В. Электронные ресурсы в информационном обеспечении научных исследований (из опыта ЦНБ АН Молдовы) / Е. В. Коротенко // Библиотеки национальных академий наук: проблемы функционирования, тенденции развития : науч.-практ. и теорет. сб. / НАН Украины, Нац. б-ка Украины им. В. И. Вернадского [и др.]. - Киев, 2008. - Вып. 6. - С. 166-170.

16. Лутовинова В. І. Новий рівень інформаційного забезпечення освітян України / В. І. Лутовинова // Педагогіка і психологія. - 2007. - № 4. - С. 133-140. - Бібліогр.: 6 назв.

17. Мацібора Н. Г. Особливості історико-бібліографічного дослідження книжкових і журнальних колекцій XIX - початку XX ст. $з$ фонду Державної науково-педагогічної бібліотеки України імені В. О. Сухомлинського / Н. Г. Мацібора // Наук. пр. Держ. наук.-пед. б-ки України ім. В. О. Сухомлинського / НАПН України ДНПБ України ім. В. О. Сухомлинського. - Київ : Пед. думка, 2010. - Вип. 2 : Всеукраїнський інформаційний ресурс з питань психолого-педагогічної науки і освіти: сучасний стан та шляхи розвитку. - С. 274-280. - Бібліогр.: 10 назв.

18. Метод проектів: традиції, перспективи, життєві результати : практико зорієнт. зб. / АПН України, Ін-т педагогіки, ДНПБ України ім. В. О. Сухомлинського ; [ред. рада: С. М. Шевцова (голова), І. Г. Срмаков (наук. кер. і ред.), О. А. Федоренко та ін.]. - Київ : [б. в.], 2003. - 504 с. - Бібліогр.: c. $491-500$.

19. Національна доктрина розвитку освіти : затв. указом Президента України від 17 квіт. 2002 р. № 347 // Проф.-техн. освіта. - 2002. - № 3. - С. 2-8.

20. Об общегосударственной системе научно-технической информации : постановление Совета Министров СССР от 29 нояб. 1966 г. № 916 // Собр. постановлений правительства СССР. - 1966. № 25 . - С. 220.

21. Пасмор Ю. В. Наукові дослідження в галузі права як об'єкт інформаційного забезпечення / Ю. В. Пасмор // Вісн. Харків. держ. акад. культури / М-во культури і туризму України, Харків. держ. акад. культури. - Харків, 2010. - Вип. 30. - С. 187-194. - Бібліогр.: 9 назв.

22. Петрина Н. О. Інформаційне забезпечення процесів освіти i науки в умовах становлення інформаційного суспільства / Петрина Н. О., Ониксимова Л. Т. // Вісн. Укр. акад. банків. справи. 2002. - № 2. - C. 96-99.

23. Пономаренко Л. Формування системи бібліографічних посібників у ДНПБ України ім. В. О. Сухомлинського / Лариса Пономаренко // Історія освітянських бібліотек України : наук. зб / АПН України, ДНПБ України ім. В. О. Сухомлинського. - Київ, 2006. - С. 75-83. - Бібліогр.: 12 назв.

24. Про Національну програму інформатизації [Електронний ресурс] : Закон України від 4 лют. 1998 р. : [станом на 16.10.2012 р.] // Законодавство України / Верхов. Рада України. - Текст. дані. - Київ, 2012. - Режим доступу: http://zakon4.rada.gov.ua/laws/show/74/98\%D0\%B2\%D1\%80 (дата звернення: 16.01.14). - Назва з екрана.

25. Профільне навчання в старшій школі: шляхи розвитку : наук.-допом. бібліогр. покажч. Вип. 1 / АПН України, ДНПБ України ім. В. О. Сухомлинського ; [упоряд.: Пономаренко Л. О., Ніколюк Л. І., Самчук Л. І. та ін.] // Освіта України. - 2005. - 6-9 груд. (№ 90/91). - С. 1-63.

26. Рогова П. І. Роль Державної науково-педагогічної бібліотеки України імені В. О. Сухомлинського у формуванні та розвитку системи інформаційних ресурсів для забезпечення вітчизняної педагогічної науки, освіти і практики / П. І. Рогова, В.І.Лутовинова, Т.В.Добко // Наук. пр. Держ. наук.-пед. б-ки ім. В. О. Сухомлинського / АПН України, ДНПБ України 
ім. В. О. Сухомлинського. - Київ, 2008. - Вип. 1 : Науково-інформаційне забезпечення освітянської галузі України. - С. 16-36 : схема. - Бібліогр.: 25 назв.

27. Рогова П. І. Система науково-інформаційного забезпечення освітянської галузі України: стан та перспективи / Рогова П. І. // Педагогічна і психологічна науки в Україні : [у 5 т.] : до 15-річчя АПН України / АПН України. - Київ : Пед. думка, 2007. - Т. 1 : Теорія та історія педагогіки. - С. 195208. - Бібліогр.: 10 назв.

28. Соколова М. Е. Информационное обеспечение научных исследований в Канаде: история и тенденции развития [Электронный ресурс] / М. Е. Соколова // Россия и Америка в XXI веке : электрон. науч. журн. - Текст. дан. - М., 2011. - № 3. - Режим доступа: http://www.rusus.ru/?act=read\&id=298 (дата обращения: 15.01.14). - Загл. с экрана.

Матеріал надійшов до редакиії 23.01.2015p.

\title{
ОПЫТ ДЕЯТЕЛЬНОСТИ ГОСУДАРСТВЕННОЙ НАУЧНО- ПЕДАГОГИЧЕСКОЙ БИБЛИОТЕКИ УКРАИНЫ ИМЕНИ \\ В. А. СУХОМЛИНСКОГО ПО ИНФОРМАЦИОННО- БИБЛИОГРАФИЧЕСКОМУ ОБЕСПЕЧЕНИЮ НАУЧНЫХ ИССЛЕДОВАНИЙ НАЦИОНАЛЬНОЙ АКАДЕМИИ ПЕДАГОГИЧЕСКИХ НАУК УКРАИНЫ
}

\author{
Самчук Лариса Ивановна \\ заведующая отделом научной информационно-библиографической деятельности \\ Государственной научно-педагогической библиотеки Украины \\ имени В. А. Сухомлинского, г. Киев, Украина \\ inform_bibl@i.ua
}

\begin{abstract}
Аннотация. Переход общества к новым экономическим и политическим реалиям обусловил радикальные изменения в системе деятельности библиотек, в том числе поиск новых парадигм информационно-библиографического обслуживания в условиях большой академической библиотеки. В статье отражены результаты деятельности Государственной научно-педагогической библиотеки Украины имени В. А. Сухомлинского на протяжении 2002-2014 гг. по информационно-библиографическому обеспечению научных исследований Национальной академии педагогических наук Украины, направленного на решение проблем, стоящих перед образовательной отраслью Украины на современном этапе. Определены перспективы деятельности Библиотеки в этом направлении.
\end{abstract}

Ключевые слова: Государственная научно-педагогическая библиотека Украины имени В. А. Сухомлинского; научно-информационная деятельность; информационнобиблиографическое обеспечение; научные исследования; структурированный библиографический список.

\section{EXPERIENCE OF ACTIVITY CONCERNING INFORMATION BIBLIOGRAPHIC SUPPORT PROVIDED BY V. O. SYKHOMLYNSKYI STATE SCIENTIFIC AND PEDAGOGICAL LIBRARY OF UKRAINE FOR SCIENTIFIC RESEARCHES DONE AT NATIONAL ACADEMY OF EDUCATIONAL SCIENCES OF UKRAINE}

\section{Larysa I. Samchuk}

Head of Scientific Information Bibliographic Work Department

V. O. Sykhomlynskyi State Scientific and Pedagogical Library of Ukraine, Kyiv, Ukraine inform_bibl@i.ua

\begin{abstract}
Social changes, new economic and political realities cause radical transformations in library activity system, especially it concerns the process of looking for new paradigms in information bibliographic service under the conditions of large academic library. The article deals with the results of activity concerning information bibliographic support provided by V. O. Sykhomlynskyi State Scientific and Pedagogical Library of Ukraine during 2002-2014 for scientific researches done at National Academy of Educational Sciences of Ukraine for solving the
\end{abstract}


problems in educational sphere of Ukraine on the present stage. Future prospects concerning library activity in this direction are outlined.

Keywords: V. O. Sykhomlynskyi State Scientific and Pedagogical Library of Ukraine; scientific information activity; information bibliographic support; scientific researches; structured bibliographic list.

\section{REFERENCES (TRANSLATED AND TRANSLITERATED)}

1. Artamonova N. Information support of medical science in Ukraine : monohrafiia / N. Artamonova. Kharkiv : Miskdruk, 2010. - 371 s. (in Ukrainian).

2. Beilis L. I. Theoretical aspects of information support research activities in libraries / L. I. Beilis // Naukovi pratsi Derzhavnoi naukovo-pedahohichnoi biblioteky im. V. O. Sukhomlynskoho / APN Ukrainy, DNPB Ukrainy im. V. O. Sukhomlynskoho. - Kyiv, 2008. - Vyp. 1 : Naukovo-informatsiine zabezpechennia osvitianskoi haluzi Ukrainy. - S. 37-44. - Bibliohr.: 8 nazv (in Ukrainian).

3. Berjozkina N. Ju. New features information and library service for scientists (for example, CSL NASB) / N. Ju. Berjozkina // Biblioteki nacional'nyh akademij nauk: problemy funkcionirovanija, tendencii razvitija : nauch.-prakt. i teoret. sb. / NAN Ukrainy, Nac. b-ka Ukrainy im. V. I. Vernadskogo [i dr.]. - Kiev, 2012. - Vyp. 10. - S. 180-186 (in Russian).

4. White Paper of National Education of Ukraine / za zah. red. V. H. Kremenia ; NAPN Ukrainy. - Kyiv : Inform. systemy, 2010. - 342 s. (in Ukrainian).

5. Verhunov V. A. Status and Prospects of Information and Library Support scientificresearch agricultural sector Ukraine / V. A. Verhunov // Bibliotekoznavstvo. Dokumentoznavstvo. Informolohiia. - 2010. - № 3. - S. 32-42. - Bibliohr.: 10 nazv (in Ukrainian).

6. GOST 7.27-80. Scientific information activity. Basic terms and definitions. - Vveden 01.01.1982. M. : Izd-vo standartov, 1981. - 14 s. (in Russian).

7. Hryshchuk Iu. V. Support for gifted students: legal, social and pedagogical aspects / Hryshchuk Yuliia Volodymyrivna // Osvitol. dyskurs. - 2014. - № 1. - S. 46-57. - Bibliohr.: 16 nazv (in Ukrainian).

8. Government social program "School of the Future" for 2007-2010 : zatv. postanovoiu Kab. Ministriv Ukrainy vid 30 serp. 2007 r. № 1071 // Ofits. visn. Ukrainy. - 2007. - № 66. - St. 2543 (in Ukrainian).

9. The research component of general education in schools and after-school educational institutions: Retrospective and Perspective : materialy Vseukr. nauk.-prakt. konf., 21 lystop. 2013 r. / MON Ukrainy, NAPN Ukrainy, In-t obdar. dytyny NAPN Ukrainy [ta in.]. - Kyiv, 2013. - 292 s. (in Ukrainian).

10. Life Competence personality: from theory to practice : nauk.-metod. posib. / APN Ukrainy, In-t pedahohiky, DNPB Ukrainy im. V. O. Sukhomlynskoho [ta in.] ; [za nauk. red. I. H. Yermakova]. Zaporizhzhia : Tsentrion, 2005. - 640 s. - Bibliohr.: s. 607-632 (in Ukrainian).

11. Proceedings of the Academy of Pedagogical Sciences of Ukraine in 2003 / APN Ukrainy ; [uporiad.: O. I. Liashenko, T. K. Polonska]. - Kyiv : [b. v.], 2004. - 357 s. (in Ukrainian).

12. Innovations in modern school teachers in the context of the dialogue of cultures : praktyko zoriient. posib. / In-t innovats. tekhnolohii i zmistu osvity MONmolodsportu Ukrainy, In-t pedahohiky NAPN Ukrainy, DNPB Ukrainy im. V. O. Sukhomlynskoho [ta in.]. - Kyiv, 2012. - 351 s. (in Ukrainian).

13. Competence Education aims: first experience, comparative approaches, perspectives : materialy Vseukr. nauk.-prakt. konf., 28 kvit. 2011 r. / In-t innovats. tekhnolohii i zmistu osvity MONmolodsportu Ukrainy, In-t pedahohiky NAPN Ukrainy, Derzh. nauk.-ped. b-ka Ukrainy im. V. O. Sukhomlynskoho ; [redkol.: Fedorenko O. A. ta in. ; zah. red.: Yermakov I. H. ta in.]. Kyiv, 2011. - 643 s. (in Ukrainian).

14. The concept of specialized education in high school : zatv. rishenniam kolehii M-va osvity i nauky Ukrainy vid 25.09.03 № 10/12-2 / APN Ukrainy, In-t pedahohiky ; uklad.: L. Berezivska, N. Bibik, M. Burda [ta in.] // Inform. zb. M-va osvity i nauky Ukrainy. - 2003. - № 24. - S. 3-15 (in Ukrainian).

15. Korotenko E. V. Electronic resources in the information support of scientific research (from experience CSL ASM) / E. V. Korotenko // Biblioteki nacional'nyh akademij nauk: problemy funkcionirovanija, tendencii razvitija : nauch.-prakt. i teoret. sb. / NAN Ukrainy, Nac. b-ka Ukrainy im. V. I. Vernadskogo [i dr.]. - Kiev, 2008. - Vyp. 6. - S. 166-170 (in Russian).

16. Lutovynova V. I. A new level of information support educators Ukraine / V. I. Lutovynova // Pedahohika i psykholohiia. - 2007. - № 4. - S. 133-140. - Bibliohr.: 6 nazv (in Ukrainian).

17. Matsibora N. H. Features historical and bibliographic study of book and journal collections XIX early XX century from the fund of the State Scientific Pedagogical Library of Ukraine Sukhomlinskiy 
/ N. H. Matsibora // Nauk. pr. Derzh. nauk.-ped. b-ky Ukrainy im. V. O. Sukhomlynskoho / NAPN Ukrainy DNPB Ukrainy im. V. O. Sukhomlynskoho. - Kyiv : Ped. dumka, 2010. - Vyp. 2 : Vseukrainskyi informatsiinyi resurs z pytan psykholoho-pedahohichnoi nauky i osvity: suchasnyi stan ta shliakhy rozvytku. - S. 274-280. - Bibliohr.: 10 nazv. (in Ukrainian).

18. Method Projects traditions, perspectives, life results : praktyko zoriient. zb. / APN Ukrainy, In-t pedahohiky, DNPB Ukrainy im. V. O. Sukhomlynskoho ; [red. rada: S. M. Shevtsova (holova), I. H. Yermakov (nauk. ker. i red.), O. A. Fedorenko ta in.]. - Kyiv : [b. v.], 2003. - 504 s. - Bibliohr.: s. 491-500 (in Ukrainian).

19. National Doctrine of Education : zatv. ukazom Prezydenta Ukrainy vid 17 kvit. 2002 r. № 347 // Prof.-tekhn. osvita. - 2002. - № 3. - S. 2-8 (in Ukrainian).

20. On the national system of scientific and technical information : postanovlenie Soveta Ministrov SSSR ot 29 nojab. 1966 g. № 916 // Sobr. postanovlenij pravitel'stva SSSR. - 1966. - № 25. - St. 220 (in Russian).

21. Pasmor Iu. V. Research in the field of law as an object of information provision / Iu. V. Pasmor // Visn. Kharkiv. derzh. akad. kultury / M-vo kultury i turyzmu Ukrainy, Kharkiv. derzh. akad. kultury. - Kharkiv, 2010. - Vyp. 30. - S. 187-194. - Bibliohr.: 9 nazv (in Ukrainian).

22. Petryna N. O. The information support of education and science in the information society / Petryna N. O., Onyksymova L. T. // Visn. Ukr. akad. bankiv. spravy. - 2002. - № 2. - S. 96-99 (in Ukrainian).

23. Ponomarenko L. Formation of bibliographical aids in DNPB Ukraine Sukhomlinskiy / Larysa Ponomarenko // Istoriia osvitianskykh bibliotek Ukrainy : nauk. zb / APN Ukrainy, DNPB Ukrainy im. V. O. Sukhomlynskoho. - Kyiv, 2006. - S. 75-83. - Bibliohr.: 12 nazv (in Ukrainian).

24. On the National Informatization Program : Zakon Ukrainy vid 4 liut. 1998 r. : [stanom na 16.10.2012 r.] [online] // Zakonodavstvo Ukrainy / Verkhov. Rada Ukrainy. - Tekst. dani. - Kyiv, 2012. Available from : http://zakon4.rada.gov.ua/laws/show/74/98-\%D0\%B2\%D1\%80 (in Ukrainian).

25. Specialized training in high school: the ways of : nauk.-dopom. bibliohr. pokazhch. Vyp. 1 / APN Ukrainy, DNPB Ukrainy im. V. O. Sukhomlynskoho ; [uporiad.: Ponomarenko L. O., Nikoliuk L. I., Samchuk L. I. ta in.] // Osvita Ukrainy. - 2005. - 6-9 hrud. (№ 90/91). - S. 1-63 (in Ukrainian).

26. Rohova P. I. The role of the State Scientific Pedagogical Library of Ukraine Sukhomlinskiy in the formation and development of information resources for national educational science, education and practice / P. I. Rohova, V. I. Lutovynova, T. V. Dobko // Naukovi pratsi Derzhavnoi naukovopedahohichnoi biblioteky im. V. O. Sukhomlynskoho / APN Ukrainy, DNPB Ukrainy im. V. O. Sukhomlynskoho. - Kyiv, 2008. - Vyp. 1 : Naukovo-informatsiine zabezpechennia osvitianskoi haluzi Ukrainy. - S. 16-36 : skhema. - Bibliohr.: 25 nazv (in Ukrainian).

27. Rohova P. Scientific and information support educational sphere Ukraine: Status and Prospects / Rohova P. I. // Pedahohichna i psykholohichna nauky v Ukraini : [u 5 t.] : do 15-richchia APN Ukrainy / APN Ukrainy. - Kyiv : Ped. dumka, 2007. - T. 1 : Teoriia ta istoriia pedahohiky. - S. 195208. - Bibliohr.: 10 nazv (in Ukrainian).

28. Sokolova M. E. Information support of scientific research in Canada: History and Development Trends [online] / M. E. Sokolova // Rossija i Amerika v HHI veke : jelektron. nauch. zhurn. - Tekst. dan. - M., 2011. - № 3. - Available from : http://www.rusus.ru/?act=read\&id=298 (in Russian). 